Georgia State University

ScholarWorks @ Georgia State University

3-1-2009

\title{
Decomposing Changes in the Aggregate Labor Force Participation Rate
}

Julie L. Hotchkiss

Federal Reserve Bank of Atlanta, julie.I.hotchkiss@atl.frb.org

Follow this and additional works at: https://scholarworks.gsu.edu/uwrg_workingpapers

\section{Recommended Citation}

Hotchkiss, Julie L., "Decomposing Changes in the Aggregate Labor Force Participation Rate" (2009). UWRG Working Papers. 143.

https://scholarworks.gsu.edu/uwrg_workingpapers/143

This Article is brought to you for free and open access by the Usery Workplace Research Group at ScholarWorks @ Georgia State University. It has been accepted for inclusion in UWRG Working Papers by an authorized administrator of ScholarWorks @ Georgia State University. For more information, please contact scholarworks@gsu.edu. 
Working Paper 2009-3-1

March 2009

Decomposing Changes in the

Aggregate Labor Force

Participation Rate

Julie L. Hotchkiss

Federal Reserve Bank of Atlanta 


\section{Decomposing Changes in the Aggregate}

Labor Force Participation Rate

Julie L. Hotchkiss

Working Paper 2009-6

March 2009

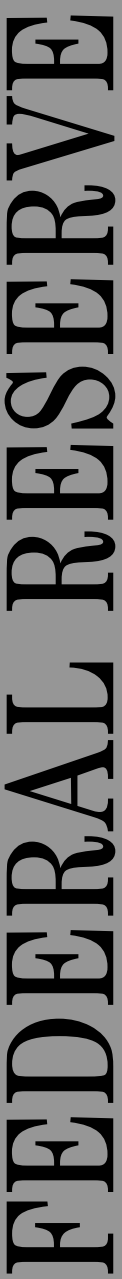




\title{
Decomposing Changes in the Aggregate Labor Force Participation Rate
}

\author{
Julie L. Hotchkiss
}

\section{Working Paper 2009-6}

March 2009

\begin{abstract}
This paper presents a simple methodology for decomposing changes in the aggregate labor force participation rate (LFPR) over time into demographic group changes in labor force participation behavior and in population share. The purpose is to identify the relative importance of behavioral changes and population changes as driving forces behind changes in the aggregate LFPR.
\end{abstract}

JEL classification: J11, J21, E24

Key words: labor force participation, decomposition, forecasting

The author thanks Alexander Ellis of the U.S. Census Bureau for his help in obtaining historical population projections. She also thanks Bruce Fallick for sharing his model's forecasts of labor force participation rates. Helpful comments were received from Robert E. Moore and John Robertson. Additional assistance was received from Elaine Clokey, Kathryn Rees, and Amanda Kay Seals. The views expressed here are the author's and not necessarily those of the Federal Reserve Bank of Atlanta or the Federal Reserve System. Any remaining errors are the author's responsibility.

Please address questions regarding content to Julie L. Hotchkiss, Research Department, Federal Reserve Bank of Atlanta, 1000 Peachtree Street, N.E., Atlanta, GA 30309-4470, 404-498-8198, julie.l.hotchkiss@atl.frb.org.

Federal Reserve Bank of Atlanta working papers, including revised versions, are available on the Atlanta Fed's Web site at www.frbatlanta.org. Click "Publications" and then "Working Papers." Use the WebScriber Service (at www.frbatlanta.org) to receive e-mail notifications about new papers. 


\section{Decomposing Changes in the Aggregate Labor Force Participation Rate}

\section{$\underline{\text { I. Introduction }}$}

The percent of the population willing to supply their labor to the market can have a profound impact on the potential growth of the economy. Human capital is an important component of the production process and an ever growing supply of labor allows an ever growing level of production without putting too much pressure on costs and, thus, prices of final products. The percent of the population willing to supply their labor is measured by the labor force participation rate (LFPR) which experienced significant growth beginning in the mid1960s, driven largely by the rise in the LFPR among women (see Figure 1). Since 1997, the aggregate LFPR began a decline that has continued (with fits and starts) through 2008.

There have been many attempts to identify the source of the relatively recent decline in the aggregate LFPR in the U.S. Some have linked the decline to cyclical factors, yet the decline started before and continued past the 2001 economic downturn, suggesting an additional structural component to the change (see Aaronson et al. 2006). Among different demographic groups, the most significant declines in labor force participation have been observed among the young and among working age women (see Cohany and Sok 2007, Lerman 2007, Mosisa and Hipple 2006, Hotchkiss 2006, Bradbury and Katz 2005, and Kirkland 2002).

These efforts to explain changes in the aggregate LFPR by focusing on behavioral changes among certain demographic groups neglects the simple algebraic contribution that population changes can make to the determination of the aggregate LFPR. This paper illustrates how changes in the aggregate LFPR can be decomposed into changes in the labor force participation behavior of different demographic groups and changes in each group's population share. This exercise demonstrates that the decline in population share of working age men and 
women actually dominated the change in participation rates among working women and among youth that have received so much recent attention. In addition, this paper illustrates how this decomposition, population projections, and simplistic assumptions about labor force participation can be used to construct a reduce-form, back-of-the envelope time path of future changes in the aggregate LFPR that matches fairly closely estimates from structural forecasting models.

\section{The Decomposition}

The aggregate LFPR can be expressed as a population weighted average of the LFPR for different demographic groups:

$L F P R_{t}=\sum_{i} p_{t}^{i} L F P R_{t}^{i}$

where $L F P R_{t}$ is the aggregate labor force participation rate at time $t, L F P R_{t}^{i}$ is the labor force participation rate of demographic group $i$, and $p_{t}^{i}$ is the population share of demographic group $i$. The change in the labor force participation rate from $t-1$ to $t$ is given by:

$L F P R_{t}-L F P R_{t-1}=\sum_{i}\left\{\left[L F P R_{t}^{i}-L F P R_{t-1}^{i}\right] p_{t}^{i}+\left[p_{t}^{i}-p_{t-1}^{i}\right] L F P R_{t-1}^{i}\right\}$

which allows the change in the aggregate $L F P R$ to be represented by the change in the participation rate of each demographic group (weighted by the group's current period population share) and by the change in the population share of each demographic group (weighted by the group's previous period LFPR).

Others have presented similar decompositions of the aggregate LFPR. Juhn and Potter (2006) decompose changes in the aggregate LFPR as described in equation (2) but fix the population weights to their 1979 levels to conclude that changes in population weights accounted for very little of the change in the aggregate LFPR between 1969 and 2004. The decomposition 
results in this paper show that, except for the period between 1970 and 1980, population changes have contributed significantly to changes in aggregate LFPR, and have even dominated most of the time since 1950 .

Aaronson et al. (2006) and Fallick and Pingle (2007) decompose deviations of the aggregate LFPR from its mean over time as a function of deviations of the population shares and demographic group participation rates from their respective historical averages. This decomposition identifies the contribution of each group's evolution in participation rates and population shares to the evolution of the aggregate LFPR. Fallick and Pingle point out that the evolution in population shares accounts for most of the evolution in the aggregate LFPR.

The focus of these earlier analyses was on how to better understand the evolution of labor force participation rates within different demographic groups. The goal of this paper is simplicity; to demonstrate how little information can be used in the exploitation of the algebraic relationship in equation (2) to understand the driving force behind the historical evolution of the aggregate LFPR and to predict the future path of the aggregate LFPR.

\section{Changes in the Aggregate LFPR from 1950 to 2008}

Table 1 presents each of the contributions of changes in labor force participation behavior and changes in population shares to five-year changes in the aggregate LFPR. The exercise can be expanded to many more demographic groups and be repeated on any frequency desired. The groups in Table 1 include everyone 16-24 years of age, women between 25 and 54 years, men between 25 and 54 years, and everyone 55 years and older. The last two rows of Table 1 show the percent of the total absolute value contributions attributable to absolute value changes in behavior (sum of absolute value changes in LFPRs across groups) and to absolute value changes 
in population shares.

Except during the period of time when women's labor force behavior was changing dramatically (1970-1980), changes in population shares contributed significantly to changes in the aggregate LFPR. Turning to the period between 2000 and 2005, the decline in population shares of men and women between 25 and 54 years of age overwhelm the downward contribution imposed by behavioral changes of 16-24 year olds and working aged women. The largest off-setting factor of those declines was an increase in labor supply behavior among the elderly.

\section{$\underline{\text { IV. Projecting Changes in Population Shares Forward }}$}

This simple accounting for changes in population shares follows a similar path projected by structural behavioral models of long-term labor force participation trends. The structural models will necessarily be more accurate in pin-pointing aggregate levels of labor force participation in the short-term, but population changes appear to be a driving force in these models when making longer-term predictions.

Figure 2 plots LFPR projections from various sources, along with the projection derived from equation (2) that accounts for U.S. Census Bureau population projections and two simple behavioral assumptions: no behavioral change from 2008 and repeated 2007-2008 behavioral change. The assumption of no behavioral change is more consistent with the projections from the structural models.

\section{$\underline{\text { V. Conclusion }}$}

This paper has shown that in spite of the attention the changing behavior of youth and 
working age women have received in trying to explain the decline in the aggregate LFPR since 2000, changing population shares accounted for an even greater portion of that decline.

Going forward, simply accounting for changes in population shares (and assuming no behavioral change) yields a projection of aggregate LFPR that is consistent with structural models produced from a variety of sources. The implication of identifying most of the anticipated declines in aggregate LFPR being rooted simply in changes in population shares is that there are predictable underlying changes that may constrain economic growth, at least through 2020 (see Aaronson et al. 2006).

However, changes in labor productivity will be important in determining how any level of labor force participation translates into economic growth. Indeed, many are convinced that immigration, gains in productivity, and normal price fluctuations in the labor market will resolve any labor shortage issues that might be expect to arise from projected declines in labor force participation (for example, see Freeman 2006 and Grossman 2005). 


\section{$\underline{\text { References }}$}

Aaronson, Stephanie; Bruce Fallick; Andrew Figura; Jonathan Pingle; and William Wascher. "The Recent Decline in the Labor Force Participation Rate and Its Implications for Potential Labor Supply." Brookings Papers on Economic Activity 1 (2006): 69-134.

Bradbury, Katharine and Jane Katz. "Women's Rise: A Work in Progress." The Federal Reserve Bank of Boston Regional Review 14(3) (Q1 2005): 58-67.

Cohany, Sharon R. and Emy Sok. "Trends in Labor Force Participation of Married Mothers of Infants." Monthly Labor Review (February 2007): 9-27.

Fallick, Bruce and Jonathan Pingle. "A Cohort-Based Model of Labor Force Participation." Finance and Economics Discussion Series \#2007-09 (April 2007).

Freeman, Richard B. "Is a Great Labor Shortage Coming? Replacement Demand in the Global Economy." NBER Working Paper \#12541 (September 2006).

Grossman, Robert J. "The Truth about the Coming Labor Shortage." HRMagazine 50(3) (March 2005).

Hotchkiss, Julie L. "Changes in Behavioral and Characteristic Determination of Female Labor Force Participation, 1975-2005." Federal Reserve Bank of Atlanta Economic Review (2006, Quarter 2): 1-20.

Juhn, Chinhui and Simon Potter. "Changes in Labor Force Participation in the United States." Journal of Economic Perspectives 20(3) (Summer 2006): 27-46.

Kirkland, Katie, "Declining Teen Labor Force Participation." Issues in Labor Statistics, Summary 02-06 (September 2002).

Lerman, Robert I. "Career-Focuesd Education and Training for Youth." In Harry J. Holzer, Demetra Smith Nightingale, eds. Reshaping the American Workforce in a Changing Economy, pp. 41-90. Washington, D.C.: Urban Institute Press, 2007.

Mosisa, Abraham and Steven Hipple. "Trends in Labor Force Participation in the United States." Monthly Labor Review (October 2006): 35-57. 
Figure 1. Labor Force Participation Rate, 1948-2008.

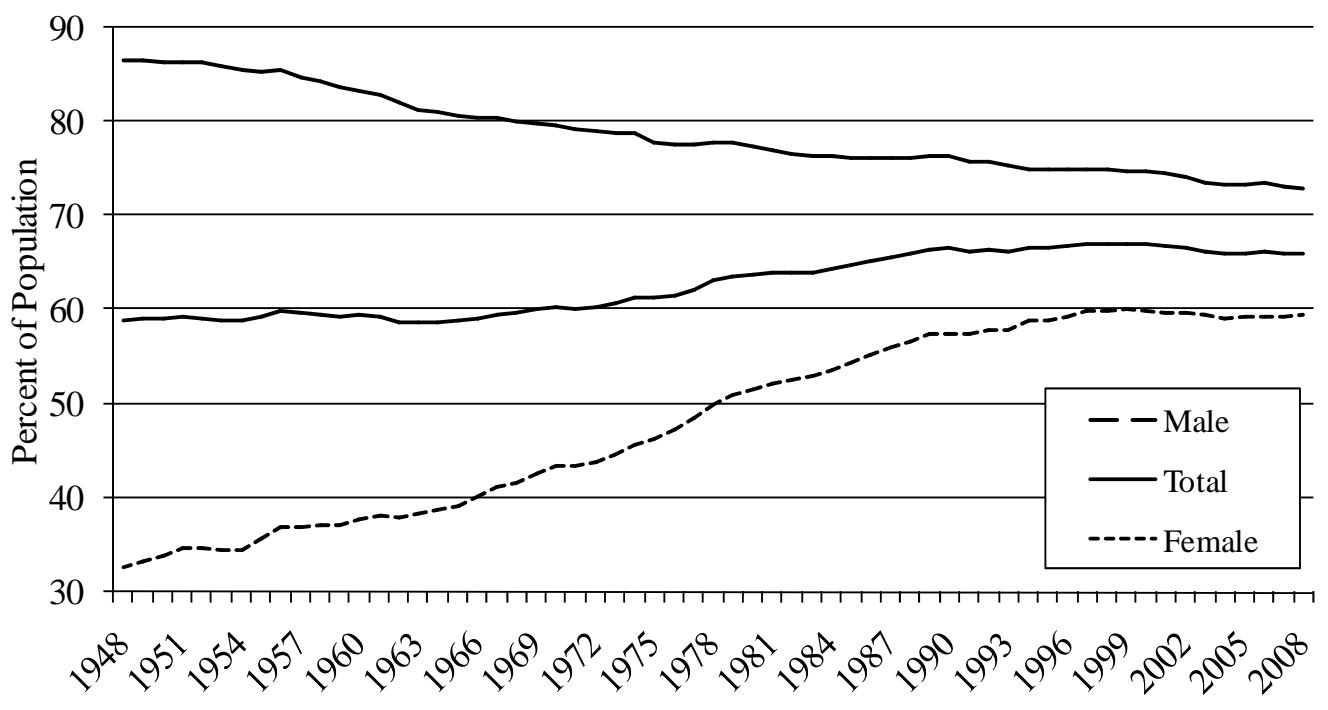

Source: Bureau of Labor Statistics.

Figure 2. Projected Aggregate LFPRs, 2004-2020.

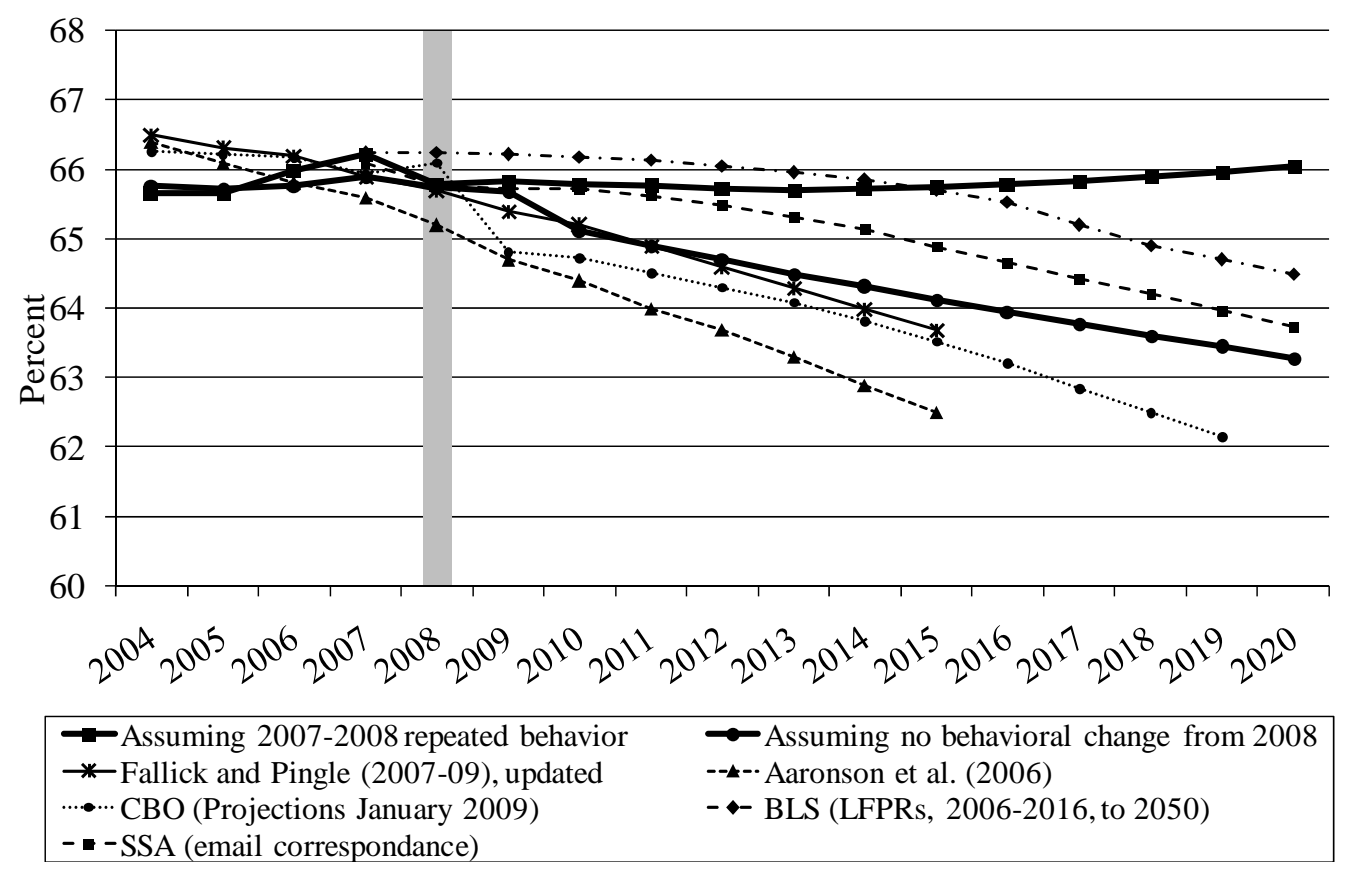

Sources (not otherwise referenced): BLS, "Labor Force and Demographic Data" <http://www.bls.gov/emp/emplab1.htm>; CBO, "The Budget and Economic Outlook: Fiscal Years 2009 to 2019 (Key Assumptions in CBO's Projection of Potential Output), January 2009 <http://www.cbo.gov/doc.cfm?index=9957>; SSA, "The 2008 Annual Report of the Board of Trustees of the Federal Old-age and Survivors Insurance and Federal Disability Insurance," 10 April 2008 <http://www.ssa.gov/OACT/TR/TR08/tr08.pdf>. 
Table 1. Contributions of changes in labor force behavior and changes in population share to changes in the aggregate LFPR.

\begin{tabular}{|c|c|c|c|c|c|c|c|c|c|c|c|c|}
\hline & $\begin{array}{l}1950- \\
1955\end{array}$ & $\begin{array}{l}1955- \\
1960\end{array}$ & $\begin{array}{l}1960- \\
1965\end{array}$ & $\begin{array}{l}1965- \\
1970\end{array}$ & $\begin{array}{l}1970- \\
1975\end{array}$ & $\begin{array}{l}1975- \\
1980\end{array}$ & $\begin{array}{l}1980- \\
1985\end{array}$ & $\begin{array}{l}1985- \\
1990\end{array}$ & $\begin{array}{l}1990- \\
1995\end{array}$ & $\begin{array}{l}1995- \\
2000\end{array}$ & $\begin{array}{l}2000- \\
2005\end{array}$ & $\begin{array}{l}2005- \\
2008\end{array}$ \\
\hline 5 Year Change in Aggregate LFPR & 0.02 & 0.10 & -0.54 & 1.54 & 0.93 & 2.43 & 1.05 & 1.77 & 0.05 & 0.49 & -1.04 & -0.07 \\
\hline Change in LFP of 16-24 year olds & -0.60 & 0.05 & -0.12 & 0.87 & 1.10 & 0.75 & 0.06 & -0.18 & -0.16 & -0.08 & -0.81 & -0.32 \\
\hline $\begin{array}{l}\text { Change in population share, } \\
16-24 \text { year olds }\end{array}$ & -1.48 & 0.90 & 1.47 & 0.95 & 0.67 & -0.46 & -1.88 & -1.18 & -0.93 & -0.12 & 0.07 & -0.12 \\
\hline Change in LFP of women, 25-54 year olds & 0.91 & 0.91 & 0.63 & 1.30 & 1.30 & 2.29 & 1.55 & 1.25 & 0.47 & 0.32 & -0.42 & 0.16 \\
\hline $\begin{array}{l}\text { Change in population share of women, } \\
25-54 \text { year olds }\end{array}$ & 0.10 & -0.40 & -0.72 & -0.47 & -0.29 & 0.04 & 0.77 & 0.89 & 0.54 & -0.21 & -0.82 & -0.51 \\
\hline Change in LFP of men, $25-54$ year olds & 0.25 & -0.11 & -0.08 & -0.22 & -0.34 & -0.05 & -0.08 & -0.14 & -0.51 & 0.00 & -0.30 & 0.00 \\
\hline $\begin{array}{l}\text { Change in population share of men, } \\
25-54 \text { year olds }\end{array}$ & 0.22 & -1.20 & -1.63 & -0.83 & -0.28 & 0.25 & 1.23 & 1.54 & 0.69 & -0.31 & -0.71 & -0.47 \\
\hline Change in LFP of $55+$ year olds & -0.23 & -0.31 & -0.40 & -0.14 & -1.13 & -0.52 & -0.69 & -0.05 & -0.03 & 0.65 & 1.38 & 0.67 \\
\hline $\begin{array}{l}\text { Change in population share, } \\
55+\text { year olds }\end{array}$ & 0.84 & 0.27 & 0.31 & 0.08 & -0.10 & 0.13 & 0.08 & -0.36 & -0.03 & 0.24 & 0.56 & 0.52 \\
\hline $\begin{array}{l}\% \text { of total contribution of (absolute } \\
\text { value) changes in LFP } \\
\% \text { of total contribution of (absolute } \\
\text { value) chanqes in Pop }\end{array}$ & $\begin{array}{l}43.00 \\
57.00\end{array}$ & $\begin{array}{l}33.29 \\
66.71\end{array}$ & $\begin{array}{l}22.98 \\
77.02\end{array}$ & $\begin{array}{l}51.94 \\
48.06\end{array}$ & $\begin{array}{l}74.26 \\
25.74\end{array}$ & $\begin{array}{l}80.37 \\
19.63\end{array}$ & $\begin{array}{l}37.43 \\
62.57\end{array}$ & $\begin{array}{l}29.02 \\
70.98\end{array}$ & $\begin{array}{l}34.62 \\
65.38\end{array}$ & $\begin{array}{l}54.36 \\
45.64\end{array}$ & $\begin{array}{l}57.32 \\
42.68\end{array}$ & $\begin{array}{l}41.56 \\
58.44\end{array}$ \\
\hline
\end{tabular}

